\title{
KONTRIBUSI KONSEP DIRI FISIK DAN MOTIVASI BERPRESTASI TERHADAP PERENCANAAN KARIER SISWA KELAS XI SMKN SE-KOTA PEKANBARU
}

\author{
Raja Arlizon, Zulfan Saam, Donal \\ Bimbingan dan Konseling FKIP Universitas Riau \\ raja arlizon@yahoo.com
}

\begin{abstract}
The general objective of this research is to describe: (a) Level of physical selfconcept boys and girls (b) The level ofstudent achievement motivationof men and women,(c) Career planning level boys and girls, (d) Differences in physical selfconcept, achievement motivation and career planning boy swith girls, (e) Contribution of physical self-concept and achievement motivation to get her to career planning under taken inclass XI SMKN Se-kota Pekanbaru. This study uses a quantitative approach with correlation and comparative methods by making proportional random sampling technique. In this study the following conclusions can be adduced: (a) Physical self-concept level boys and girls in general are in the medium category, (b) The level of student achievement motivation of men and women in general are in the category of being, (c) Level career planning to ward boys and girls in general are at a high category, (d) There are differences in physicalself-concept of boysandgirls, (e) There were no differences in achievement motivation and career planning boys and the women, (f) There contribution of physical self-concept and a chievement motivation on student career planning direction.
\end{abstract}

Keyword: physicalself-concept, achievement motivation, career planning

\section{PENDAHULUAN}

Siswa SMK (Sekolah Menengah Kejuruan) berada pada tahap kritis antara dua pilihan menjelang tamat SMK yakni apakah melanjutkan ke perguruan tinggi atau bekerja untuk mencari nafkah. Pada tahap ini juga, usia para siswa SMK berada pada tahap akhir masa remaja atau menjelang memasuki masa dewasa. Dalam memasuki masa dewasa ini banyak yang menjadi pertimbangan remaja terutama berkaitan dengan masalah pekerjaan ataupun merencanakan karier masa depannya.

Merencanakan karier masa depan merupakan persiapan remaja sebelum masuk ke dunia kerja serta merupakan tugas perkembangan remaja.Remaja idealnya dalam merencanakan sesuatu karier dan pekerjaan itu disesuaikan 
dengan potensi yang dimilikinya. Berbicara masalah tugas perkembangan, karier ini merupakan salah satu aspek tugas perkembangan siswa SLTA/SMK dari sebelas aspek tugasperkembangan. Menurut Sunaryo Kartadinata (dalam Supriatna, Ed., 2010) yaitu:Aspek-aspek tugas perkembangan pada usia SLTA antara lain: (1) Landasan hidup religius, (2) Landasan perilaku etis, (3) Kematangan emosional, (4) Kematangan intelektual, (5) Kesadaran tanggung jawab, (6) Peran sosial sebagai pria dan wanita, (7) Penerimaan diri dan pengembangannya, (8) Kemandirian perilaku ekonomis, (9) Wawasan persiapan karier, (10) Kematangan hubungan dengan teman sebaya, (11) Persiapan diri untuk pernikahan dan hidup berkeluarga.

Mengingat karier ini merupakan aspek tugas perkembangan, ada beberapa persoalan yang terjadi pada masa SMA menurut Hardiani dan Irman (2009) berkaitan dengan karier diantaranya sebagai berikut; (a) ketidak mampuan mengikuti pembelajaran dengan baik, tandai dengan rendahnya prestasi belajar atau nilai akademik, (b) selalu ragu dan tidak mampu melakukan pilihan yang tepat dan cocok untuk diri, (c) kereguan dan ketidaktahuan dalam melanjutkan pendidikan pada jenjang yang lebih tinggi, melakukan pilihan pendidikan dan jurusan, (d) melalukan pilihan pendidikan dan jurusan namun merasa tidak cocok dengan bakat dan minat yang dimiliki, (e) ketidaktahuan untuk mendapatkan kerja, pada hal berbagai persyaratan kerja telah dimiliki.

Menurut Williamson (dalam Manrihu, 1992) mengambarkan masalahmasalah karir siswa diantaranya; (1) tidak adanya pilihan-pilihan, maksudnya individu tidak dapat membeda-bedakan dengan baik diantara okupasi-okupasi yang ada guna memilih salah satu dan terjun kedalamnya, (2) pilihan tidak pasti, maksudnya suatu pilihan telah dilakukan tapi orang itu tidak pasti tentang pilihan itu, (3) pilihan yang tidak bijaksana, maksudnya terdapat ketidak sesuaian kemampuan-kemampuan atau minat-minat individu dan okupasi yang ia pilih, (4) ketidak sesuaian antara minat-minat dan bakat-bakat dalam tipe atapun taraf dari kedua sifat ini ketika berinterakasi dalam menetukan pilihan.

Dari gambaran persoalan di atas, dapat dipahami bahwa; (1) sebagian siswa SMK belum mampu dalam menentukan arah perencanaan kariernya kedepan yang akan dijalankannya, apakah melajutkan pendidikan perguruan tinggi atau Raja Arlizon, Kontribusi Konsep Diri Fisik Dan Motivasi Berprestasi Terhadap Perencanaan Karier Siswa Kelas XI SMKN Se-Kota Pekanbaru 
terjun kedunia kerja, (2) sebagiansiswakurang memiliki keinginan dalam mengikuti pelajaran di sekolah, rendahya motivasi siswa untuk berprestasi.

Dalam Pendapat lain beberapa faktor yang mempengaruhi pilihan karier individu sebagaimana dinyatakan oleh Lambert, dkk. (dalam Manrihu, 1992), bahwa ada beberapa faktor yang mempengaruhi pilihan karier individu yaitu:faktor internal dan eksternal. Dalam factor internal ini salah satu diantaranya adalah jenis kelamin, mempengaruhi pilihan karier karena pria dan wanita mempunyai sikap yang berbeda terhadap pekerjaan, misalnya bagi pria karier yang dipilih biasanya menjadi pekerjaan seterusnya, sehingga untuk meyakinkan bahwa pilihan tersebut akan memuaskan dirinya, mereka cenderung membutuhkan banyak waktu dan pemikiran untuk mempersiapkan diri. Sedangkan pada wanita masih berlaku anggapan bahwa bekerja akan berakhir setelah mereka menikah. Masalah pada wanita seringkali mereka harus memutuskan apakah mereka akan berkarier atau tidak, dan apakah secara temporer atau permanen. Selain itu, pandangan tradisional tentang perbedaan kemampuan antara pria dan wanita, membuat wanita mempunyai sikap yang negatif terhadap pekerjaan tertentu yang dianggap bersifat maskulin.

Adapun rumusan masalah dalam penelitian ini adalah sebagai berikut: (a) bagaimana tingkat konsep diri fisik siswa laki-laki dan perempuan (b) bagaimana tingkat motivasi berprestasi siswa laki-laki dan perempuan, (c) bagaimana tingkat perencanaan karier siswa laki-laki dan perempuan, (d) apakah terdapat perbedaan konsep diri fisik, motivasi berprestasi dan perencanaan karier siswa laki-lakidengan perempuan, (e) apakah terdapat Kontribusi konsep diri fisik terhadap perencanaan karier, (f) apakah terdapat Kontribusi motivasi berprestasi terhadap perencanaan karier siswa, (g) apakah terdapat Kontribusi konsep diri fisik dan motivasi berprestasi secara bersama-sama terhadap perencanaan karier yang dilaksanakan pada siswa kelas XI SMKN Se-kota Pekanbaru.

Sesuai dengan rumusan masalah yang dikemukakan di atas maka tujuan umum dalam penelitian ini adalah untuk mendeskripsikan: (a) Tingkat konsep diri fisik siswa laki-laki dan perempuan, (bTingkat motivasi berprestasi siswa laki-laki dan perempuan, (c) Tingkat perencanaan karier siswa laki-laki dan perempuan, (d) Perbedaan konsep diri fisik, motivasi berprestasi dan perencanaan karier siswa 
laki-lakidengan perempuan, (e) Kontribusi konsep diri fisik terhadap perencanaan karier, (f) Kontribusi motivasi berprestasi terhadap perencanaan karier siswa, (g) Kontribusi konsep diri fisik dan motivasi berprestasi secara bersama-sama terhadap perencanaan karier yang dilaksanakan pada siswa kelas XI SMKN Sekota Pekanbaru.

Manfaat dari penelitian ini diharapkan dapat memberikan sumbangan bagi pengembangan teori tentang permasalahan yang dihadapi oleh siswa disekolah dalam bidang pengembangan arah karier siswa dan dapat dijadikan sumber informasi pendidikan dalam penerapan layanan bimbingan dan konseling di sekolah khususnya terkait bimbingan karier.

\section{METODE PENELITIAN}

Penelitian ini menggunakan pendekatan kuantitatif dengan metode korelasional dan komperatif. Adapun yang menjadi populasi dalam penelitian ini adalah seluruh siswa kelas XI SMKN Se-kota Pekanbaru yang terdaftar pada semester ganjil Tahun Ajaran 2014/2015 dengan teknik pengambilan sampel proportional random sampling. Sample penelitian adalah $25 \%$ dari jumlah siswa SMKN Se-kota Pekanbaru tersebut.

Tabel 1

Populasi dan Sampel Penelitian

\begin{tabular}{|l|l|c|c|c|}
\hline No & \multicolumn{1}{|c|}{ Sekolah } & \multicolumn{2}{|c|}{ Populasi } & Sampel \\
\cline { 3 - 4 } & & Laki-Laki & Perempuan & \\
\hline $\mathbf{1}$ & SMKN 1 Pekanbaru & 107 & 286 & $\mathbf{9 9}$ \\
\hline $\mathbf{2}$ & SMKN 4 Pekanbaru & 141 & 132 & $\mathbf{6 8}$ \\
\hline $\mathbf{3}$ & $\begin{array}{l}\text { SMKN Pertanian } \\
\text { Pekanbaru }\end{array}$ & 189 & 129 & $\mathbf{7 9}$ \\
\hline $\mathbf{4}$ & $\begin{array}{l}\text { SMKN Kehutanan } \\
\text { Pekanbaru }\end{array}$ & 67 & 26 & $\mathbf{2 4}$ \\
\hline \multicolumn{2}{|l|}{ JUMLAH } & $\mathbf{5 0 4}$ & $\mathbf{5 7 3}$ & $\mathbf{2 7 0}$ \\
\hline
\end{tabular}

Jenis data yang dikumpulkan pada penelitian ini menggunakan angket/kuesioner tertutup yang dikembangkan untuk masing-masing variabel penelitian. Data yang akan dikumpulkan teridiri dari tiga jenis data, yakni: data tentang konsep diri siswa, motivasi berprestasi siswa, dan data tentang Perencanaan Karier siswa dengan mengunakan Skala Model Likert.

Raja Arlizon, Kontribusi Konsep Diri Fisik Dan Motivasi Berprestasi Terhadap Perencanaan Karier Siswa Kelas XI SMKN Se-Kota Pekanbaru 
Teknik analisis data dalam penelitian ini mengunakan rumus persentase dan rata-rata digunakan untuk mendeskripsikan data konsep diri fisik, motivasi berprestasi dan perencanaan karier siswa laki-laki dan perempuan. Untuk melihat perbedaan konsep diri fisik, motivasi berprestasi dan perencanaan karie laki-laki dan perempuan mengunakan rumus t-test, dan untuk melihat kontribusi antar variabel dengan mengunakan alat analisis regresi sederhana dan regresi ganda.

\section{HASIL PENELITIAN DAN PEMBAHASAN}

Berdasarkan hasil pengolahan angket konsep diri fisik, motivasi berprestasi dan perencanaan kariersiswa laki-laki dan perempuan kelas XI SMKN Se-kota Pekanbaru pada tabel berikut ini:

Tabel 2

Tingkat konsep diri fisik, motivasi berprestasi dan perencanaan karier siswa perempuan kelas XI SMKN Se-kota Pekanbaru

\begin{tabular}{|l|c|c|c|c|c|}
\hline \multicolumn{1}{|c|}{ Variabel } & $\mathbf{N}$ & Minimum & Maximum & Mean & $\begin{array}{c}\text { Std. } \\
\text { Deviation }\end{array}$ \\
\hline $\begin{array}{l}\text { Konsep diri fisik laki- } \\
\text { laki }\end{array}$ & 126 & 24 & 61 & 48.8651 & 5.76798 \\
\hline $\begin{array}{l}\text { Konsep diri fisik } \\
\text { perempaun }\end{array}$ & 144 & 31 & 59 & 47.4028 & 5.95827 \\
\hline $\begin{array}{l}\text { Motivasi berprestasi } \\
\text { laki-laki }\end{array}$ & 126 & 46 & 82 & 66.3413 & 6.77780 \\
\hline $\begin{array}{l}\text { Motivasi berprestasi } \\
\text { perempaun }\end{array}$ & 144 & 48 & 87 & 66.5208 & 7.27095 \\
\hline $\begin{array}{l}\text { Perencanaan karier } \\
\text { laki-laki }\end{array}$ & 126 & 33 & 91 & 74.9286 & 8.57268 \\
\hline $\begin{array}{l}\text { Perencanaan karier } \\
\text { perempuan }\end{array}$ & 144 & 33 & 94 & 73.6667 & 10.60677 \\
\hline
\end{tabular}

Berdasarkan hasil analis data konsep diri fisik siswa laki-laki kelas XI SMKN Se-kota Pekanbaru berada pada kategori sedang dengan rata-rata 48.86. Hal ini menurut Puspasari (2007), kesadaran seorang anak akan tubuhnya, merupakan cara seseorang melihat tubuhnya. Proses untuk mengenali bentuk tubuh tidak hanya melihat bentuk fisik dari pantulan cemin, namun juga bagaimana seseorang menghayati bentuk fisiknya dan ketika seseorang mengalami rasa tertentu pada fisiknya, penghayatan akan terfokus kepada perasaan itu. Efek yang timbul dari 
persoalan ini adalah adanya kemunculan perasaan rendah diri dan kecenderungan untuk menghilangkan identitas fisiknya itu.

Bedasarkan hasil pengolahan data pada tabel 2 bahwa konsep diri fisik siswa perempuan kelas XI SMKN Se-kota pekanbaru berada pada kategori sedang dengan rata-rata 47.40. Ada beberapa hal yang membentuk konsep diri fisik siswa. Menurut Sullivan (dalam Sobur, 2009) dari Rakhmat, menjelaskan bahwa jika kita diterima orang lain, dihormati dan disenangi karena keadaan diri kita, kita cenderung bersikap menghormati dan menerima diri kita. Sebaliknya, bila orang lain selalu meremehkan kita, menyalahkan dan menolak kita, kita akan cenderung tidak akan menyenangi diri kita.Penilaian yang diberikan itu berkaitan seberapa dekatnya orang memberikan penilaian terhadap individu yang dinilai juga menentukan. Dewey dan Humber (dalam Sobur, 2009) menamainya affective others yaitu orang lain yang mempunyai ikatan emosional dengan kita. Senyuman, pujian, penghargaan, dan pelukan mereka, menyebabkan kita menilai diri kita secara positif.

Berdasarkan hasil analisis data pada Tabel 2 motivasi berprestasi siswa lakilakikelas XI SMKN Se-kota Pekanbaru berada pada kategori sedang dengan ratarata 66.34. Hal ini sejalan menurut Mc Clelland dkk (dalam Yusuf, 2002) dalam temuan penelitian menyatakan bahwa tiap individu mempunyai kebutuhan berprestasi (need for achievement) dalam dirinya yang besar dalam satu rentang dua kecenderungan yang berlawanan, yaitu kecenderungan untuk meraih sukses/berhasil (need for success) dan kecenderungan untuk menghindari kegagalan (need for avoidance). Dalam pendapat di atas menjelaskan bahawa motivasi untuk berprestasi merupakan sebuah kebutuhan seseorang yang semua orang berkeinginan untuk mencapai sebuah kesukses baik dalam berteman maupun dalam belajar di dunia pendidikan yang muaranya sukses dalam kehidupan masa depan yang cerah.

Berdasarkan hasil analisis data penelitian pada tabel 2 bahwa motivasi berprestasi siswa perempuan kelas XI SMKN Se-kota Pekanbaru berada pada kategori sedang dengan rata-rata 66.52. Seseorang dalam berprestasi ada sebenarnya yang melatar belakangi menurut Mc Clelland (2010) bahwa prestasi seseorang sebenarnya dikendalikan oleh banyak faktor bukan saja untuk 
memenuhi kebutuhan makan tetapi seseorang berprestasi juga untuk mendapatkan persetujuan sosial, kekuasaan, atau pengetahuan juga tidak kalapentingnya faktor kemampuan. Dari penjelasan di atas dapat dipahami bahwa banyak hal yang memdorong seseorang untuk terus berprestasi. Maka dalam memahami sebuah kejadian ada yang melatar belakangi seseorang berprestasi ini juga perlu di dalami agar apa yang ingin dicapai itu bisa dimotivasi lagi agar tambah bersemangat untuk mencapai target yang sudah dibuat itu dan untuk yang mempunyai motivasi yang sangat rendah perlunya meningkatkannya.

Dari hasil analisis pada Tabel 2 tingkat perencanaan karier siswa laki-laki kelas XI SMKN Se-kota Pekanbaru berada pada kategori tinggi dengan rata-rata 74.92. Idealnya siswa sudah mempunyai cita-cita masa depan dan telah memahami secara menyeluruh tentang arah pilihan yang yang telah dicitacitakannya itu. Sesuai dengan pendapat Havighurst (dalam Mudjiran, 2007) menyatakan bahwa salah satu tugas perkembangan remaja adalah memiliki kemampuan untuk memilih dan mempersiapkan diri untuk karier. Sebagai remaja yang berkembang mereka sudah memiliki keyakinan akan nilai-nilai untuk bekal hidup dalam karier, memiliki ketetapan karier yang akan ditekuni, dan mengarahkan diri mereka dalam pendidikan dan kepribadian sesuai dengan tuntutan karier yang mereka akan pilih. Mereka telah menyadari bakat dan minat mereka yang nantinya akan mendukung karier mereka.

Hasil analis membuktikan bahwa pada Tabel 2 tingkat perencanaan karier siswa perempuan kelas XI SMKN Se-kota Pekanbaru berada pada kategori tinggi dengan rata-rata 73.66. Menurut Ginzberg (dalam Winkel, 1997), remaja yang berada dalam tahapan tentatif mengalami proses transisi yang ditandai oleh pengenalan secara berangsur-angsur persyaratan kerja, serta pengenalan bakat, minat, kemampuan, imbalan kerja, nilai dan persefektif waktu. Jadi siswa di sini sudah mampu mengenal persyaratan kerja, mengenali kemampuannya serta memahami perspektif waktu dan nilai-nilai yang nanti akan dihadapi di dunia kerja.

Berdasarkan uraian di atas diketahui bahwa perencanaan karier siswa terus berkembangan seiring berjalanan waktu dan juga memalui pendidikan. Menurut Yusuf, (2002) menyatakan bahwa faktor yang mempengaruhi seseorang memilih pekerjaan antara lain: (1) pengetahuan dan wawasan, (2) kecerdasan, (3) 
kecakapan, (4) bakat, (5) minat, (6) sikap, (7) nilai-nilai, (8) sifat-sifat pribadi. Faktor lain yang juga mempengaruhi seseorang dalam memilih sebuah pekerjaan diantaranya; (1) karakteristik kerja, (2) jenis-jenis kerja, (3) prospek kerja atau peluang kerja, (4) lingkungan psiko-sosial kerja.

Untuk mengetahui perbedaan konsep diri fisik, motivasi berprestasi dan perencanaan karier siswa antara laki-laki dan perempuankelas XI SMKN Se-kota Pekanbaru dapat dilihat pada tabel berikut ini:

Tabel 3

Perbedaan konsep diri fisik, motivasi berprestasi dan perencanaan karier siswa laki-laki dengan perempuan kelas XI SMKN Se-kota Pekanbaru

\begin{tabular}{|l|c|c|c|c|c|c|}
\hline & & $\mathbf{F}$ & $\mathbf{S i g}$. & $\mathbf{t}$ & $\mathbf{t}_{\text {tabel }}$ & $\mathbf{d f}$ \\
\cline { 2 - 7 } $\begin{array}{l}\text { Perbedaan konsep } \\
\text { diri fisik siswa laki- } \\
\text { lakidengan } \\
\text { perempuan }\end{array}$ & $\begin{array}{c}\text { Equal } \\
\text { variances } \\
\text { assumed }\end{array}$ & 0.919 & 0.33 & 2.042 & 1.960 & 268 \\
\hline $\begin{array}{l}\text { Perbedaan } \\
\text { motivasi } \\
\text { berprestasi siswa } \\
\text { laki-lakidengan } \\
\text { perempuan }\end{array}$ & $\begin{array}{c}\text { Equal } \\
\text { variances } \\
\text { assumed }\end{array}$ & 0.927 & 0.33 & -0.209 & 1.960 & 268 \\
\hline $\begin{array}{l}\text { Perbedaan karier } \\
\text { perencanaan karier } \\
\text { siswa laki- } \\
\text { lakidengan } \\
\text { perempuan }\end{array}$ & $\begin{array}{c}\text { Equal } \\
\text { variances } \\
\text { assumed }\end{array}$ & 1.278 & 0.25 & 1.065 & 1.960 & 268 \\
\hline
\end{tabular}

Melihat dari hasil analisis data pada Tabel 3 yang menunjukkan bahwa terdapat perbedaan konsep diri fisik antara siswa laki-laki dan perempuan $t_{\text {hitung }}$ $2.042>t_{\text {tabel }}$ 1.960. Sesuai dengan Faktor-faktor yang mempengaruhi konsep diri menurut Rapport (dalam Saam, 2009) menyatakan bahwa: (1) perubahan fisik, (2) hubungan dengan keluarga, (3) hubungan dengan lawan atau sesama jenis, (4) perkembangan kognitif, dan (5) identitas personal.

Berdasarkan hasil analisis data tabel 3 yang menyatakan bahwa tidak terdapat perbedaan yang signifikan antara tingkat motivasi berprestasi siswa ditinjau dari jenis kelamin laki-laki dan perempuan $t_{\text {hitung }}-0.209<t_{\text {tabel }} 1.960$. Hal ini sejalan dengan pendapat Mc Clelland dkk (dalam Yusuf, 2002) dalam temuan penelitian menyatakan bahwa: Tiap individu mempunyai kebutuhan berprestasi (need for achievement) dalam dirinya yang tersebar dalam suatu rentang dua 
kecenderungan yang berlawanan, yaitu kecederungan untuk meraih sukses/keberhasilan (need for success) dan kecenderungan untuk menghindari dari kegagalan (need for avoidance).

Dari beberapa penelitian terkait dengan tingkat perencanaan karir yang membandingkan antara laki-laki dan perempuan memberikan kesimpulan tidak ada perbedaan di antaranya $t_{\text {hitung }} 1.065<t_{\text {tabel }} 1.960$. Dengan hasil temuan dalam penelitian ini kiranya mendukung pendapat Muri Yusuf (2005) memberikan penjelasan yang berhubungan dengan karir yakni : "Perjalanan karir seseorang tidaklah dapat dilihat secara terpisah-pisah dari salah satu sisi: siapa ia (minat, bakat, sifat, kemauan, nilai-nilai, intelegensi dan nilai-nilai, dll.), atau pendidikan yang pernah diterimanya, peluang karir yang ada, atau psycho-social di tempat kerja, kekerabatan atau garis keturunan, atau pengalaman seseorang di masa lampau, maupun situasi dan kehidupan dalam masyarakat.

Bandura pada tahun 1977 (dalam Larson 1994) menyatakan bahwa para perempuan mempunyai level kecemasan yang lebih tinggi karena mereka merasa kehilangan kontrol dalam area kehidupan yang penting. Konflik peran dan kecemasan diduga melemahkan kompromi antara kebutuhan akan keluarga dan karir.

Untuk mengetahui kontribusi konsep diri fisik, motivasi berprestasi terhadap perencanaan karier siswa antara laki-laki dan perempuankelas XI SMKN Se-kota Pekanbaru dapat dilihat pada tabel berikut ini: 
Tabel 3

Hasil Analisis Korelasi Variabel Konsep Diri Fisik $X_{1}$, Motivasi Berprestasi $\mathrm{X}_{2}$ dengan Perencanaan Karier $(\mathrm{Y})$

\begin{tabular}{|l|l|l|l|l|l|l|l|}
\hline Model & \multicolumn{1}{|c|}{$\mathbf{R}$} & $\begin{array}{c}\mathbf{R} \\
\text { Square }\end{array}$ & $\begin{array}{l}\text { Adjusted } \\
\mathbf{R} \text { Square }\end{array}$ & $\begin{array}{c}\text { Std. Error } \\
\text { of the } \\
\text { Estimate }\end{array}$ & $\mathbf{F}_{\text {hitung }}$ & $\mathbf{F}_{\text {tabel }}$ & Sig. \\
\hline $\begin{array}{l}\text { Konsep } \\
\text { diri fisik } \\
\text { Perenc } \\
\text { anaan } \\
\text { Karier }\end{array}$ & 0.234 & 0.055 & 0.051 & 9.46128 & 15.541 & 3.89 & 0.001 \\
\hline $\begin{array}{l}\text { Motivasi } \\
\text { berpresta } \\
\text { si } \\
\text { Perencar } \\
\text { aan } \\
\text { Karier } \mathrm{Y}\end{array}$ & 0.383 & 0.146 & 0.143 & 8.99104 & 45.975 & 3.89 & 0.000 \\
\hline \begin{tabular}{l}
$\mathrm{X}_{1} \mathrm{X}_{2} \mathrm{Y}$ \\
\hline
\end{tabular} & 0.422 & 0.178 & 0.172 & 8.83814 & 28.966 & 3,89 & .000 \\
\hline
\end{tabular}

Hasil analisis data pada Tabel 3 memberikan informasi bahwa terdapat kontribusi konsep diri fisik terhadap perencanaan karier siswa kelas XI SMKN Sekota Pekanbarusebesar R Square0.055 atau 5,5\%. Hasil peneltian ini sejalan dengan pendapat Super menyatakan (dalam Winkel dan Astuti, 2004) bahwa indikasi yang kuat bahwa gambaran diri yang vokasional berkembang selama pertumbuhan fisik dan perkembangan kognitif; perkembangan ini berlangsung melalui observasi terhadap orang-orang yang memegang jabatan tertentu, melalui penghayatan pengalaman hidup dan memelalui pengaruh yang diterima dari lingkungan hidup.

Dalam pendapat di atas memberikan pemahaman seiring dengan perkembanagan fisik seseorang akan memikirkan arah kariernya. Winkel dan Astuti (2007) bahwa keadaan jasmani mempengaruhi karir seseorang, dengan ciri-ciri yang dimiliki seseorang seperti tinggi badan, berat badan, jenis kelamin, dalam bidang pekerjaan tertentu mempersyaratkan keadaan jasmani berkaitan dengan ciri-ciri fisik seseorang.

Berdasarkan analisis data pada Tabel 3 terdapat kontribusi motivasi berprestasi terhadap perencanaan karier siswa kelas XI SMKN Se-kota 
Pekanbaru sebesar R Square0.146 atau 14,6\%. Hasil penelitian di atas sejalan dengan pendapat Morris (dalam Osipow, 1983) menemukan bahwa siswa yang tinggi dalam motivasi berprestasi tampaknya membuat pilihan pekerjaan yang mencerminkan kemauan untuk memikirkan kemungkinan-kemungkinan tingkat berisiko menengah dibandingkan siswa yang memiliki motivasi berprestasi rendah.

Dalam penjelasan lain menurut McClelland (dalam Anderson dan Faust, 1973) menyatakan bahwa individu yang memiliki motivasi berprestasi sudah mempunyai tujuan jangka panjang. Tujuan jangka panjang itu tentunya ingin sukses dalam karier nantinya.Tujuan-tujuan yang telah dibuat merupakan sebuah standar yang akan dicapai, hal ini bertujuan untuk menghindari kegagalan dan meraih sebuah kesuksesan. Dalam pendapat yang lain, motivasi prestasi tinggi menurut McClelland (2010) memberikan kontribusi terhadap karier yang sukses dalam bisnis daripada sebaliknya, karena anak-anak dengan motivasi Prestasi tinggi, sudah berperilaku dengan cara yang sama sebelum mereka mulai dalam karier mereka.

Berdasarkan hasil analisis data pada Tabel 3 bahwa terdapat Kontribusi konsep diri fisik dan motivasi berprestasi secara bersama-sama terhadap perencanaan karier siswa kelas XI SMKN Se-kota Pekanbaru sebesar R Square 0.178 atau $17,8 \%$. Konsep diri fisik dan motivasi berprestasi adalah salah satunya faktor dalam perencanaan karier siswa. Seperti pandangan Super (dalam Winkel dan Hastuti, 2004) bahwa perencanaan karier itu berlingkup sangat luas, karena dipandang sebagai suatu proses yang mencakup banyak faktor. Faktor tersebut untuk sebagian terdapat dalam diri individu, dan sebagain lagi terdapat dalam lingkungan hidupnya, yang semua itu berinteraksi satu sama lain yang semuanya bersama membentuk proses arah pilihan karier seseorang.

McClelland (2010) motivasi Prestasi tinggi memberikan kontribusi terhadap karier yang sukses dalam bisnis daripada sebaliknya, karena anak-anak dengan motivasi Prestasi tinggi, sudah berperilaku dengan cara yang sama sebelum mereka mulai dalam karier mereka. Lebih rinci Shertzer dan stone (dalam Winkel dan Hastuti, 2004) perkembangan karir merupakan gabungan faktor-faktor psikologis, sosial, pendidikan, fisik, ekonomis, dan kesempatan yang bersama- 
sama membentuk jabatan seseorang. Gabungan ini mencakup banyak faktor internal dan eksternal. Dari pendapat di atas dapat dipahami konsep diri fisik dan motivasi berprestasi bisa mempengaruhi arah perencanaan karier seseorang.

\section{KESIMPULAN}

Berdasarkan temuan dan pembahasan hasil penelitian bisa dikemukakan kesimpulan-kesimpulan sebagai berikut: (a) Tingkat konsep diri fisiksiswa laki-laki dan perempuan secara umum berada dalam kategori sedang. (b) Tingkat motivasi berprestasi siswa laki-laki dan perempuan secara umum berada pada katagori sedang. (c) Tingkat arah perencanaan karier siswa laki-laki dan perempuan secara umum berada pada katagori tinggi. (d) Terdapat perbedaan konsep diri fisik siswa laki-laki dan perempuan. (e) Tidak terdapat perbedaan motivasi berprestasi dan perencanaan karier siswa laki-laki dan perempuan.(f) Terdapat kontribusi konsep diri fisik terhadap arah perencanaan karier siswa. (g) Terdapat kontribusi motivasi berprestasi terhadap arah perencanaan karier siswa SMK, (h) Terdapat kontribusi konsep diri fisik dan motivasi berprestasi terhadap arah perencanaan karier siswa.

\section{DAFTAR PUSTAKA}

Calhoun, J. F. dan Acocelia, Joan Ross. Psikologi Tentang Penyesuaian dan Hubungan Kemanusian. Terjemahan oleh Satmoko.1995. Semarang: IKIP Semarang Press.

Departemen Pendidikan Nasional. 2008. Kamus Besar Bahasa Indonesia. Jakarta: Gramedia.

Dillard, J. M.. 1985. Life Long Carier Planning. Charles E. Merril Publishing Co. Ohio.

Hadiarni dan Irman. 2009. Konseling Karir. Batusangkar: STAIN Batusangkar Press.

Issacson, L. E. 1986. "Career Information in Counseling and Career Development". Fourth Edition. Boston: Allyn and Bacon, Inc.

McClelland, D. C. 2010. The Achieving Sosiety. Princeton, New Jersi: Martino Publishing. 
Puspasari, A. 2007. Mengukur Konsep Diri Anak. Jakarta: PT Elex Media Komputindo Kelompok Gramedia.

Santrock, J. W. Perkembangan Remaja. Terjemahan oleh Shinto B. Adelar dan Sherly Saragih. 2003. Jakarta: Erlangga.

Remaja Edisi 11 Jilid 1.Terjemahan oleh Benedictine Widyasinta. 2007. Jakarta: Erlangga.

Sharf, R. S. 1992. Applying Career Development Theory Of Counselling. California: wadswort, inc.

Widjaya, A.W. 1987. Perencanaan Sebagai Fungsi Manajemen. Jakarta: Bina Aksara.

Winkel, W.S. dan Astuti, 2007. Bimbingan dan konseling di Institusi Pendidikan. Yogyakarta: Media Abadi

Supriatna, M. (Ed.). 2010. Bimbingan dan Konseling Berbasis Kompetensi. Bandung: Rajawali Press.

Sunarto, Kamanto. 2011. Pengantar Sosiologi. Lembaga Penerbit FE-Ul. Jakarta.

Yusuf, A.M. 2002. Kiat Sukses Dalam Karier. Bogor: Ghalia Indonesia.

. 2013. "Metodologi Penelitian: Kuantitatif, Kualitatif dan Penelitian Gabungan". Padang: UNP Press. 